Editorial

\title{
Editorial: Politicization of EU Trade Policy Across Time and Space
}

\author{
Dirk De Bièvre ${ }^{1}$, Patricia Garcia-Duran ${ }^{2}$, Leif Johan Eliasson ${ }^{3, *}$ and Oriol Costa ${ }^{4}$ \\ ${ }^{1}$ Department of Political Science, University of Antwerp, 2000 Antwerpen, Belgium; E-Mail: dirk.debievre@uantwerpen.be \\ 2 Department of Economic History, Institutions and Policy and World Economy, University of Barcelona, 09034 Barcelona, \\ Spain; E-Mail: patriciagarciaduran@ub.edu \\ ${ }^{3}$ Department of Political Science and Economics, East Stroudsburg University, East Stroudsburg, PA 18301, USA; E-Mail: \\ jeliasson@esu.edu \\ ${ }^{4}$ Faculty of Political Science and Sociology, Universitat Autònoma de Barcelona, 08193 Cerdanyola del Vallès, Spain; E-Mail: \\ oriol.costa@uab.cat
}

* Corresponding author

Submitted: 24 March 2020 | Published: 31 March 2020

\begin{abstract}
This editorial provides an introduction to the thematic issue "Politicization of EU Trade Policy Across Time and Space." The academic editors place the issue in the context of the current literature, introduce the contributions, and discuss how the articles, individually and jointly, add to the state of the art.
\end{abstract}

\section{Keywords}

European Union; institutions; politicization; trade negotiations; trade policy

Issue

This editorial is part of the issue "Politicization of EU Trade Policy across Time and Space" edited by Dirk De Bièvre (University of Antwerp, Belgium), Oriol Costa (Universitat Autònoma de Barcelona, Spain/IBEI, Spain), Leif Johan Eliasson (East Stroudsburg University, USA) and Patricia Garcia-Duran (University of Barcelona, Spain).

(C) 2020 by the authors; licensee Cogitatio (Lisbon, Portugal). This article is licensed under a Creative Commons Attribution 4.0 International License (CC BY).

Since the global financial crisis, political populism has risen throughout Europe and North America, and the global trade governance regime is regularly maligned by the Trump administration. As a standard bearer for multilateralism, the European Union (EU) is now focusing primarily on bilateral trade negotiations, arguing that a widening net of agreements elevate bilateral achievements to the multilateral level. During this time, its trade policy has also become increasingly politicized. This became particularly evident during the EU's negotiations with the United States (US) on the Transatlantic Trade and Investment Partnership (TTIP), and in the later stages of the negotiations with Canada on the Comprehensive Economic and Trade Agreement (CETA). The issues raised and proposals made during these negotiations became highly salient for a large number of actors, with opinions increasingly polarized. Scholars studying the negotiations directed their attention toward the outside lob- bying activities of civil society organizations' (CSOs), the emphasis on regulation in new-generation trade agreements, and Europeans' perceptions of the US (Laursen \& Roederer-Rynning, 2017).

The contributors to this thematic issue unpack the concept of politicization in its different forms and manifestations. They explore variation in politicization across different EU trade negotiations, trace the evolution of politicization over time, and gauge the reasons for varying degrees and manifestations of trade politicization across EU Member States. Rather than treating politicization as a singular resultant of a particular negotiation, or as a fixed cause for change in negotiating behaviour, we conceive of politicization as a process, in which different negotiations interact, that evolves over time, and that takes a different form at different levels across Member States. Politicization is not only the result of action-the outcome-but can also be the context in which actors en- 
gage and take decisions. In particular, the contributions look into, and compare, the politicization of EU trade negotiations within advanced industrialized countries as well as within Latin-American, African, and Caribbean trading partners. They examine when and how we can expect politicization, analyse the framing of communication used by the European Commission and CSOs, examine the politicization of specific issues, and assess variation in politicization across Member States through carefully selected case studies.

In their contribution, De Bièvre and Poletti (2020) look at differentiated trade politicization across EU bilateral trade negotiations. They argue that in order to understand why there was politicization over TTIP (and (ETA), one must weigh the relative explanatory force one can accord to parliamentary control over trade policy, the depth and comprehensiveness of the trade agreement, and the relative economic size of the trading partner. Since these explanations fail to account for the lack of politicization over parallel or similar EU negotiations, they argue that they can more usefully be considered structural background conditions upon which to build explanations grounded in agency enacted by interest groups. They therefore sketch several avenues, flowing from interest group and public opinion research, for investigating interest groups' identification of latent issues that can be made salient by tapping into, and then mobilizing, public opinion through framing and outside lobbying.

Andrea Bianculli's (2020) article looks at politicization in negotiating partners' countries during the EU-MERCOSUR negotiations. She shows that internal politicization in MERCOSUR countries was not accompanied by contestation or an undermining of negotiating authority. On the contrary, she argues that internal politicization, in conjunction with external pressures and demands by trading partners, especially the EU, to negotiate with the entire MERCOSUR bloc rather than with separate countries led to constant, unwavering support for the negotiations.

Anke Moerland and Clara Weinhardt (2020) also analyse politicization in EU partners, comparing politicization in the Caribbean and Western Africa. They find that, in contrast to the state of the art on the politicization of EU external relations, deep integration measures do not automatically fuel politicization in partner countries. Whereas their inclusion in the EU-Caribbean deal did not lead to politicization, the absence of deep regulatory commitments in the EU-West Africa deal did not forestall significant internal contestation. They conclude that trade politicization is not automatically triggered when a country is negotiating a deep trade agreement, nor when CSOs have resources. Yet, politicization is less possible and less probable when CSOs lack resources.

Two contributions probe deeper into the types of discourses both civil society and public actors engage in when politicizing EU trade negotiations, and when they react to such societal mobilisation. Gabriel Siles-Brügge and Michael Strange (2020) look at CSOs' activism and framing during trade negotiations. They show that there is a consistency between how CSOs discussed and addressed issues in TTIP and what they had done during the campaign against the General Agreement on Trade on Services, during the Doha round negotiations. In both cases, CSOs wanted to construct a transnational network of activists, and, accordingly, built a transnational frame for a transnational campaign. The need for transnational solidarity meant that their collective action frames did not rest on establishing a polarizing fault-line between political activity at the domestic (local and national) and supranational levels.

Patricia Garcia-Duran, Leif Johan Eliasson, and Oriol Costa (2020) examine political leaders' responses to politicization over TTIP (and CETA) and its aftermath by examining the rhetorical response from the European Commission, while also presenting some of the ways policy changed as a result of politicization. Using a qualitative analysis of the European Commission's speeches, they show that the Commission responded to politicization by using a rhetorical counter-strategy, grounded in a pre-existing doctrine of so-called 'managed globalization,' initially coined at the turn of the century. Whereas initially elements of the managed globalization doctrine were used to lessen polarization, but without touting the doctrine, the Commission's communication from 2016 onward was explicitly framed using the language of 'managed globalization.'

The next set of four contributions dig deeper into variation in politicization across EU Member States. Niels Gheyle (2020) presents a comparison of domestic coalitions that emerged in Germany, Ireland, and Belgium, during TTIP negotiations, and argues that there is differentiated politicization across settings because of differences in CSOs' mobilization of resources. He then identifies the elements that contribute to such resources, including the mobilization of experts, the availability of previously existing domestic alliances, and an inclusive framing approach used to establish a diverse coalition.

Sophie Meunier and Christilla Roederer-Rynning (2020) tackle the riddle of why France was largely 'missing in action' during the anti-TTIP campaign. They show that despite a large and strong network of CSOs, underpinned by anti-American sentiments and strong politicization in neighbouring countries, French public opinion could not be mobilized against TTIP and CETA. They challenge the explanatory power of resource mobilisation, arguing that the relatively subdued politicization and resistance to TTIP in France was not due to lack of CSO activism, but rather the success of depoliticization efforts undertaken by the French government.

In her contribution, Aukje van Loon (2020) makes a case for taking domestic level variables seriously. She argues that by examining domestic material interests (business associations and trade unions), societal ideas (voters and non-governmental organizations) dominant in these countries' domestic politics, as well as 
their interaction with national institutions, one can better understand the United Kingdom (UK) and German governments' positions during TTIP negotiations. She shows that the inclusive, consensus-oriented institutions in Germany can account for a gradual decline in public support for transatlantic trade negotiations in Germany, whereas majoritarian competition-oriented decision making in the UK fail to trigger such an outcome, despite very similar material benefits expected from TTIP.

The last two contributions draw attention to the relationship between politicization and authority shifts. Anna Herranz-Surrallés (2020) tackles the question of how politicization of Investor-State Dispute Settlement can lead to vertical authority shifts (between international and national levels), as well as horizontal authority shifts (between public and private forms of governance). She shows how these very different institutional consequences pan out through a comparison of reforms within the framework of the United Nations Commission on International Trade Law and the Energy Charter Treaty.

María García (2020) looks at the challenging case of the UK, where a vertical authority shift is taking place. If Brexit is considered a trade policy issue (given that the $\mathrm{EU}$ is a major trading partner), then the ongoing Brexit debate is the most important instance of trade politicization in the UK, more than TTIP, and one that has ended with re-nationalization. Like Herranz-Surrallés (2020), she thus underlines that authority shifts also imply a shift in the focus of legitimacy demands, which is the argument underpinning the idea of 'taking back control' used by Brexit supporters.

The existing literature on European trade policy concurs that support for deep and comprehensive trade agreements with large or similarly sized countries varies across Member States (Young, 2017) and that some major drivers of politicization include the depth of the integration/trade agreement, the degree of CSO attention and mobilization, and differences in public receptiveness to actors' frames (Laursen \& RoedererRynning, 2017; Leblond \& Viju-Miljusevic, 2019; Young, 2017). The contributions to this thematic issue, in various ways, assess and qualify these variables' explanatory power. In and of themselves, they do not suffice (either separately or jointly) to explain differentiated trade politicization (De Bièvre \& Poletti, 2020; Moerland $\&$ Weinhardt, 2020). They may have to be combined with domestic institutional factors (Meunier \& RoedererRynning, 2020; van Loon, 2020), transnational politicization (Siles-Brügge \& Strange, 2020), the interaction between interest group agency and public opinion augmenting the salience of certain issues (De Bièvre \& Poletti, 2020), and the influence of previous politicization (Bianculli, 2020; García, 2020; Garcia-Duran et al., 2020; Gheyle, 2020; Herranz-Surrallés, 2020).

Most contributions to this thematic issue also explicitly or implicitly engage with two prevalent hypotheses in the literature about the politicization of international politics and EU integration-i.e., that politicization is a function of authority transfer, and that politicization depends on the existence of a network of challengers with sufficient resource mobilization. In fact, the contributions point out the limits of these hypotheses, and the ways in which they interact with each other and with other variables. While none of the contributions challenge the need for resource mobilization (García, 2020; Gheyle, 2020), several show that possessing resources is not a sufficient condition for politicization (Meunier \& Roederer-Rynning, 2020; Moerland \& Weinhardt, 2020). As for politicization being a function of authority transfer, a key contribution is that authority shifts are not simply a question of more or less authority transferred to the international level. As part of a dynamic process, these shifts can be both vertical (among different levels of public authority) and horizontal (between public and private forms of authority); they may help re-legitimate institutions or de-legitimate them, provoke politicization, but also be the result of politicization (García, 2020; Herranz-Surrallés, 2020). From this perspective, politicization could be seen as a barometer of the legitimacy of the prevailing equilibrium between vertical and horizontal authority transfers.

We hope you will thoroughly enjoy the different contributions in this issue. Clearly, trade policy making by the EU has become a variegated and dynamic process, looking much like politics itself. Perhaps this is even the underlying theme of the entire thematic issue: the arrival of normal politics to EU trade policy.

\section{Acknowledgments}

We acknowledge research funding from the Research Foundation Flanders (FWO), the Research Fund of the University of Antwerp (BOF), the National R+D Plan of the Spanish Ministry of Economy and Competiveness under Grant CSO2016-79205-P, “EU-NormCon, Normative Contestation in Europe: Implications for the EU in a Changing Global Order," and the Institut Barcelona d'Estudis Internacionals.

\section{Conflict of Interests}

The authors declare no conflict of interests.

\section{References}

Bianculli, A. C. (2020). Politicization and regional integration in Latin America: Implications for EU-MERCOSUR negotiations? Politics and Governance, 8(1), 254-265.

De Bièvre, D., \& Poletti, A. (2020). Towards explaining varying degrees of politicization of EU trade agreement negotiations. Politics and Governance, 8(1), 243-253.

García, M. (2020). Slow rise of trade politicisation in the UK and Brexit. Politics and Governance, 8(1), 348-359. 
Garcia-Duran, P., Eliasson, L. J., \& Costa, O. (2020). Managed globalization 2.0: The European commission's response to trade politicization. Politics and Governance, 8(1), 290-300.

Gheyle, N. (2020). Huddle up! Exploring domestic coalition formation dynamics in the differentiated politicization of TTIP. Politics and Governance, 8(1), 301-311.

Herranz-Surrallés, A. (2020). 'Authority shifts' in global governance: Intersecting politicizations and the reform of investor-state arbitration. Politics and Governance, 8(1), 336-347.

Laursen, F., \& Roederer-Rynning, C. (2017) Introduction: The new EU FTAs as contentious market. Journal of European Integration, 39(7), 763-779.

Leblond, P., \& Viju-Miljusevic, C. (2019). EU trade policy in the twenty-first century: Change, continuity and challenges. Journal of European Public Policy, 26(12), 1836-1846.
Meunier, S., \& Roederer-Rynning, C. (2020). Missing in action? France and the politicization of trade and investment agreements. Politics and Governance, 8(1), 312-324.

Moerland, A., \& Weinhardt, C. (2020). Politicisation 'reversed': EU free trade negotiations with West Africa and the Caribbean. Politics and Governance, 8(1), 266-276.

Siles-Brügge, G., \& Strange, M. (2020). National autonomy or transnational solidarity? Using multiple geographic frames to politicize EU trade policy. Politics and Governance, 8(1), 277-289.

van Loon, A. (2020). The selective politicization of transatlantic trade negotiations. Politics and Governance, 8(1), 325-335.

Young, A. R. (2017). European trade policy in interesting times. Journal of European Integration, 39(7), 909-923.

\section{About the Authors}

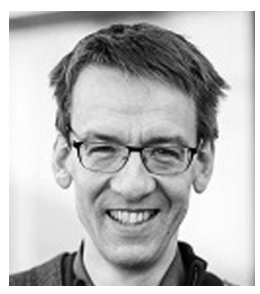

Dirk De Bièvre is Professor and Chair of the Department of Political Science at the University of Antwerp (Flanders, Belgium). He obtained his PhD in Social and Political Sciences from the European University Institute in Firenze, Italy, in 2002. Before moving to Antwerp, he was a Postdoctoral Research Fellow at the Max Planck Max Planck Institute for Research on Collective Goods in Bonn (2002-2003) and at the Mannheim Centre for European Social Research (2003-2006).

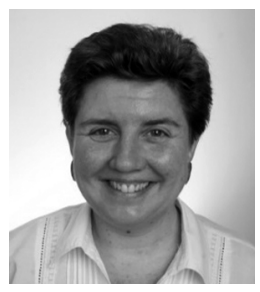

Patricia Garcia-Duran is Associate Professor at the University of Barcelona (Department of Economic History, Institutions and Policies and World Economy). She is also Researcher at the Observatory of European Foreign Policy at the Barcelona Institute of International Studies (IBEI). In recent years, her work has focused on EU trade policy and the World Trade Organization. She has published in several refereed journals, including the Journal of European Public Policy, Journal of European Integration and the Journal of World Trade.

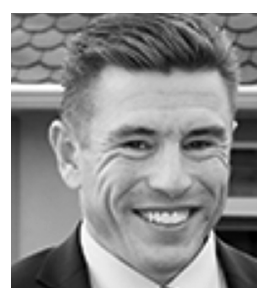

Leif Johan Eliasson is Professor of Political Science at East Stroudsburg University. His research focuses on European trade policy and transatlantic trade relations. In addition to three books, he has published in journals such the Journal of European Public Policy, Journal of European Integration, World Economy, and the Journal of World Trade.

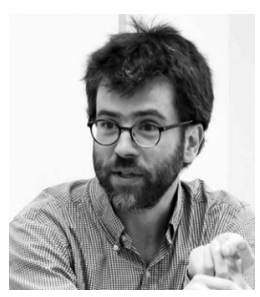

Oriol Costa is Associate Professor of International Relations at the Autonomous University of Barcelona (UAB). He is also a Senior Research Associate at the Barcelona Institute of International Studies (IBEI). His research deals with EU external relations, and has focused more recently on whether and how it has become more politicized and contested. He has published in journals such as Journal of European Public Policy, Comparative European Politics, Cooperation and Conflicts, Mediterranean Politics, and Cambridge Review of International Affairs. 